\title{
RBI'S Initiative in Promoting Financial Literacy A Study with Special Reference to Mumbai
}

\author{
*Dr Sweta Kumari \\ Assistant Professor, Amity University \\ Corresponding Author: Dr V.V.Krishna Reddy
}

\begin{abstract}
Financial literacy is the process by which investors improve their understanding of financial markets, products, concepts and risks. Financial literacy is important because it benefits not only the consumers, but also the financial system and the economy. Financial literacy causes consumers to behave in a particular way, and develop particular attitudes concerning money. The microeconomic benefits to the household extend out to produce macroeconomic benefits for the economy and the financial system and thus it is an important function of the central bank of any country to develop adequate financial literacy among its people. The Reserve bank of India has been actively engaged in development of various financial literacy programs in the recent years This study is motivated by the need to determine common man's ability to understand and use financial information, the impact of financial literacy programs and the role of central bank in creating more financially savvy consumers. The major objectives of this study are to study and understand the different financial literacy programs of the Reserve bank of India and to measure the effectiveness of financial literacy programs. An attempt has also been made to determine the level of financial literacy among target group and to identify the factors having an influence on financial behavior and attitude. The study has great implication for policy makers and developers of financial literacy programs. The study will be particularly useful to investors in better financial decision making and creating awareness about the importance of financial education. It will also provide a platform for future research covering the role of SEBI, government, academicians, private banks and other financial bodies in field of financial literacy
\end{abstract}

Keywords: Financial literacy, financial market, financial resources, policy makers, investors.

\section{Introduction}

Financial literacy is the process by which investors improve their understanding of financial markets, products, concepts and risks. Through information and objective advice, they develop the skills and confidence to become more aware of financial risks and opportunities and make informed choices to improve their financial position. Financial education primarily relates to personal finance, which enables individuals to take effective action to improve overall well-being and avoid distress in financial matters. Financial literacy goes beyond the provision of financial information and advice. It is the ability to know, monitor, and effectively use financial resources to enhance the well-being and economic security of oneself, one's family, and one's business.

In recent years, financial literacy has gained the attention of central bank, banking companies, government agencies, grass-roots consumer, com-munity interest groups, and other organizations. Interested groups, including policymakers, are concerned that consumers lack a working knowledge of financial concepts and do not have the tools they need to make decisions most advantageous to their economic well-being. Such financial literacy deficiencies can affect an individual's or family's day-to-day money management and ability to save for long-term goals such as buying a home, seeking higher education, or financing retirement. Ineffective money management can also result in behaviors that make consumers vulnerable to severe financial crisis. Numerous factors have led to a complex, specialized financial services marketplace that requires consumers to be actively engaged if they are to manage their finances effectively .Financial literacy has therefore assumed greater significance.

\section{Financial Literacy: Some Definitions}

Financial literacy means different things to different people, and this is reflected most clearly in the many definitions used in the literature. For some it is quite a broad concept, encompassing an understanding of economics and how household decisions are affected by economic conditions and circumstances. For others, it focuses quite narrowly on basic money management: budgeting, saving, investing and insuring

According to RBI, Financial literacy can broadly be defined as "providing familiarity with and understanding of financial market products, especially rewards and risks, in order making informed choices".

The European Commission defines financial literacy as

"the capability of consumers and small business owners to understand retail financial products with a view to making informed financial decisions".

This is a valuable definition for this study because it sees financial literacy as a capability, and therefore as the ability of consumers to exercise choice. Financial literacy is not just about the mechanics of checking bank accounts, or even budgeting for future savings. The definition can be expanded to include learning about selecting between a multiplicity of choices, setting personal financial goals, and reflecting on values about money

\begin{tabular}{lll|l|}
\hline DOI: $10.9790 / 5933-0804016271$ & www.iosrjournals.org & 62 Page
\end{tabular}




\section{Need for financial literacy}

Financial literacy has assumed greater importance in the recent years, as financial markets have become increasingly complex and as there is information asymmetry between markets and the common person, leading to the latter finding it increasingly difficult to make informed choices.

Literature review revealed that India is among the world's most efficient financial markets in terms of technology, regulation and systems. It also has one of the highest savings rate in the world .While people in India prefer to save, where the savings are invested is a cause for concern. Investments by households have been more into either bank fixed deposits, risk free government-backed securities and low-yielding instruments, or in non-financial assets. A majority of our households do not use modern financial markets. Unless the common person becomes a wiser investor and is protected from wrong doings, wealth creation for the investor and the economy will remain a distant dream. We need to convert a country of savers into a nation of investors

Financial literacy is becoming increasingly important, and not just for investors. It is becoming essential for the average family trying to decide how to balance its budget, buy a home, fund the children's education and ensure an income when they retire. Of course people have always been responsible for managing their own finances on a day to day basis spend on a holiday or save for new furniture; how much to put aside for a child's education or to set them up in life - but recent developments have made financial literacy and awareness increasingly important for financial well-being. For one thing, the growing sophistication of financial markets means consumers are not just choosing between interest rates on two different bank loans or savings plans, but are rather being offered a variety of complex financial instruments for borrowing and saving, with a large range of options. At the same time, the responsibility and risk for financial decisions will have a major impact on an individual's future life. As life expectancy is increasing, the managing of finances is particularly important as individuals will be enjoying longer periods of retirement.

Individuals will not be able to choose the right savings or investments for themselves, and may be at risk of fraud, if they are not financially literate. But if individuals do become financially literate, they will be more likely to save and to challenge financial service providers to develop products that truly respond to their needs, and that should have positive effects on both investment levels and economic growth

Financial literacy is considered an important adjunct for promoting financial inclusion and ultimately, financial stability. Both developed and developing countries, therefore, are focusing on programmes for financial literacy. In India, the need for financial literacy is even greater considering the low levels of general literacy and the large section of the population, which still remains out of the formal financial loop. For emerging economies, financially educated consumers can help ensure that the financial sector makes an effective contribution to real economic growth and poverty reduction. But financial literacy is also crucial for more developed economies, to help ensure consumers save enough to provide an adequate income in retirement while avoiding high levels of debt that might result in bankruptcy and foreclosures.

The information available on consumer financial literacy is worrying for two reasons - not only do individuals generally lack an adequate financial background or understanding to navigate today's complex market, but unfortunately they also generally believe that they are far more financially literate than is really the case. The need for better informed and financially literate consumers has been prompted by the proliferation of complex financial products in the market, the growing number of people reaching retirement, the shift towards personal responsibility to fund retirement, and the advent of electronic and internet banking. Financial products are now increasingly difficult to assess for people unfamiliar with basic financial and economic concepts, and thus the performance of financial products is almost impossible to predict in an informed way. Education is therefore needed for people to become financially literate, knowledgeable and informed.

\section{Benefits of financial literacy}

Financial literacy is important because it benefits consumers, the financial system and the economy. Financial literacy causes consumers to behave in a particular way, and develop particular attitudes concerning money. The microeconomic benefits to the household extend out to produce macroeconomic benefits for the economy and the financial system. Financial literacy gives consumers and households the knowledge and skills necessary to assess the suitability of financial products and investments. This translates into a number of benefits. Financial literacy increases awareness of the importance of saving, and planning for retirement. This awareness is shown to increase planning and saving for retirement. Financial literacy results in financial efficiency. This refers to the use of financial products and investing without waste and unnecessary cost. Financial literacy therefore gives consumers the ability to live more efficiently, without unnecessary cost and waste. Financial efficiency can include selecting the best value product on the market, and paying the lowest possible price on the market for a particular product or service.

Financially literate consumers are more financially efficient. Seeking and purchasing 'better, cheaper and more appropriate products and services can drive efficiencies in the financial industry'. This leads to increased competition, better quality products and greater innovation and diversity in the market. Knowledge of consumer rights and contracts also allows consumers to evaluate products more carefully and as a result demand more from suppliers. In other words financial literacy leads to financial freedom and thus the importance of financial literacy cannot be undermined. Financially literate consumers can also create a more competitive, innovative, safe, stable, accessible, disciplined and liquid financial system and markets. Financial literacy bolsters market discipline, which is the collective consumer influence on financial institutional behaviour, making these institutions 'more likely to operate in a safe, sound and efficient manner

\section{Primary objectives}

\section{Objectives}

$>$ To study the level of financial literacy among target group

$>$ To study the influence of financial literacy on investment choice decision

$>$ To identify the important factors affecting financial attitude and behavior among the target respondents. 
$>$ To analysis the impact of gender on financial attitude and behavior.

$>$ To measure the effectiveness of financial literacy programs* of Reserve Bank of India with reference to ** *website, press release, workshops

** creating general financial awareness ,financial planning for the future, protection from fraud, overcoming a financial crisis, awareness about central banking functions, knowledge about financial markets and products

Secondary objectives

$>\quad$ To study and understand the different financial literacy initiatives of Reserve bank of India

$>$ To suggest ways for improving the impact and reach of financial literacy program.

\section{Research Methodology}

The research will be exploratory in nature as it is a new and a developing topic, particularly in India. Adequate flexibility will be provided for considering the different aspects of the problem. Data will be collected through survey method.

\section{Primary data}

The study intends to collect primary data using questionnaire and in depth interview .The questionnaire will be divided suitably to cover the demographic details, the level of financial education ,financial behavior ,awareness about financial literacy programs and the impact of such programs .Effectiveness of the programs will be measured by suitable questions on a likert scale .

\section{Secondary data}

The secondary data has been be collected by extensive literature review, publications and press release of Reserve bank, thorough study of the topic from previous studies, news papers, journals and the internet

\section{Sampling technique}

Stratified sampling will be used to cover people of different gender, age groups, income levels, different educational background and different investment levels.

\section{Research tools}

Correlation has been applied to measure the relationship between financial literacy and investment choice decision . Factor analysis has been used to determine the important factors having an influence on financial behavior and attitude Further ANOVA was applied to measure the difference in financial behavior and attitude w.r.t gender. Average mean and t-test has been used to test the most effective media w.r.t general financial awareness, financial planning for the future, protection from fraud, overcoming a financial crisis, awareness about central banking functions, knowledge about financial markets and products .

\section{Literature Review}

Financial literacy or financial education can broadly be defined as 'providing familiarity with and understanding of financial market products, especially rewards and risks, in order making informed choices.

Organization for Economic Co-operation and Development (OECD) has defined financial education as ${ }^{1}$

'the process by which financial consumers/ investors improve their understanding of financial products, concepts and risks, and through information, instruction and/or objective advice, develop the skills and confidence to become more aware of financial risks and opportunities, to make informed choices, to know where to go for help, and to take other effective actions to improve their financial well-being'.

The main findings of a survey of 1,003 Americans conducted by Princeton Survey Research Associates International (PSRAI) ${ }^{2}$ on behalf of the National Foundation for Credit Counseling, Inc. (NFCC) was that only a minority keep close track of expenses, More get financial education at home than school and less than half check their credit history. The purpose of the survey was to establish a benchmark survey that identifies what Americans know about their finances and how receptive they are to professional financial advice and education. When asked what kind of setting would suit them best when learning about financial issues, one third of the public prefer a traditional classroom or seminar setting while nearly as many favor a one-on-one approach. There are a range of incentives that people say would motivate them to learn more about financial issues, such as reduced insurance on a car or home, reduced mortgage points, a free savings or checking account, reduced interest on a credit card and reduced interest on a loan.

1. The importance of Financial Education, Organisation for Economic Cooperation and Development (OECD) Policy Brief; July 2006

2. Summary Report Financial Literacy Survey Prepared by Princeton Survey Research Associates International for the National Foundation for Credit Counseling 2007

In the current financial crisis, children and youth are uniquely impacted by household finance complexities. Moments of financial trouble are teachable opportunities for children and youth to learn about personal finance and to improve their own money management skills. However, comprehensive strategies for educating them about personal finance have not yet emerged. This reviews of the literature ${ }^{1}$ explores the state of youth financial education and policy, including definitions and measures of effectiveness. Delineating a range of approaches to the delivery and assessment of youth financial education, this paper reports on impact data and best practices and highlights some controversies.. The need for financial education for children and youth is clear and compelling.

Not understanding saving and investing means not evaluating investment options, missed opportunities, and often ultimately very serious financial problems. On the other hand, by understanding and acting through proper saving and investing principles, financial freedom is a very real. The possible outcome of not being financially aware may be ${ }^{2}$ poor investment choices; Not understanding investment choices; Not saving because of a lack of confidence; Not making use 
of government saving incentives that allow taxes to be saved; Not enough money at retirement; Too much debt; Not understanding what is happening in the economy and the financial world around us.

\section{The Effectiveness of Youth Financial Education: A Review of the Literature Journal of Financial Counseling and Planning Volume 20, Issue 12009.}

2. (C) 2005-2010 savingandinvesting.com LLC

Focusing on imparting financial education to the people of the country, the Reserve Bank of India (RBI) has organized financial outreach camps in some of the remote villages of India ${ }^{1}$. RBI has launched the second phase of its outreach camps in the northeast .Addressing a public meeting at Changki village in Mokokchung district in Nagaland on Wednesday, the executive director of RBI, V S Das said, "RBI has been taking up several programmes to financially educate people in the rural areas of the country since its platinum jubilee celebrations in 2009-10. It has already organized outreach camps that focus on the importance of financial literacy for financial inclusion in 218 villages across the country so far."

In RBI- OECD workshop on delivering financial literacy: challenges, strategies and instruments march $2010^{2}$, Finance minister Dr. Pranab Mukherjee underlined that fact half of Indian population has no bank account and just over half of world's adult population do not use formal financial services to save or borrow. He also underlined that while there is no nationwide financial literacy programme in India, an increasing number of broad and far reaching institutions- specific projects are developed such as the comprehensive one developed by the Reserve Bank of India, or the more recent one launched by the Securities and Exchange Board of India, or other self- regulatory organisations (Indian Banks Associations, Banking Code and Standards Board of India). Dr. Duvviri Subbarao then underlined the importance of robust consumers' financial skills for the development of sound financial services market and of the Indian economy as a whole.

1. timesofindia.indiatimes.com > City 9 Feb 2012

2. RBI-OECD workshop on delivering financial literacy : challenges, strategies and instruments march 2010,banglore www.rbi.in.org

The Reserve Bank has undertaken a project titled 'Project Financial Literacy'. ${ }^{1}$ The objective of the project is to disseminate information regarding the central bank and general banking concepts to various target groups, such as, school and college going children, women, rural and urban poor, defense personnel and senior citizens. It would be disseminated to the target audience with the help, of banks, local government machinery, NGOs, schools, and colleges through presentations, pamphlets, brochures, films, as also through the Reserve Bank's website. The Reserve Bank has already created a link on its web site for the common person to give him/her the ease of access to financial information in English and Hindi, and 12 Indian regional languages.A financial education site was launched on November 14, 2007 commemorating the Children's Day. Mainly aimed at teaching basics of banking, finance and central banking to children in different age groups, the site will also eventually have information useful to other target groups, such as, women, rural and urban poor, defense personnel and senior citizens. The comic books format has been used to explain complexities of banking, finance and central banking in a simple and interesting way for children. The site has films on security features of currency notes of different denominations and a games section. The games currently on display have been especially designed to familiarize school children with India's various currency notes. The site will soon be available in Hindi and twelve regional languages. In addition, with a view to promoting financial awareness, the Reserve Bank conducted essay competitions for school children on topics related to banking and financial inclusion. The Bank has also been participating in exhibitions to spread financial literacy.

\section{Reserve bank of India report on financial literacy and credit counseling $3^{\text {rd }}$ April 2008}

RBI also participated in the exhibition aboard the 'Azadi Express' a train to commemorate 150 years of India's freedom struggle which began in the year $1857 .{ }^{1}$ The train during a year's run will cover several places in the country. Recently, the Reserve Bank launched 'RBI Young Scholars Award' Scheme amongst students undergoing undergraduate studies to generate interest in and create awareness about the banking sector and the Reserve Bank. Under the scheme, up to 150 young scholars would be selected through country-wide competitive examination and awarded scholarships to work on short duration projects at Reserve Bank.

At the Annual Conference of the International Network of Financial Services Ombudsman Schemes in Vancouver, ${ }^{2}$ Canada, Chakrabarty said: "It is widely believed that the complex financial instruments that contributed to the financial crisis essentially had their basis in the boom period home loans, the credit quality of which was poorly assessed. The costs of such irresponsible lending and borrowing were borne by tens of millions of taxpayers in the form of the bail-out of beleaguered institutions." Chakrabarty said current levels of transparency made it difficult for consumers to identify and understand the fine print from a large volume of information, creating an information asymmetry between the financial intermediary and the consumer. He said future initiatives should aim to empower the customer to make a studied and reasonable choice on a financial product or service. "Financial literacy is a must to gauge the needs of the population and financial institutions, so that financial resources can be translated into higher economic growth while minimizing the financial stability risks," he said.

1. www.rbi.in.org

2. www.centralbanking.com

This research by Brenda J. Cude, University of Georgia and Frances C. Lawrence, Louisiana State University ${ }^{1}$ assessed the financial management practices of college students using a set of recommended practices. One conclusion from the research is that some college students are not managing their finances well, because they have not adopted the set of recommended practices. Another conclusion is that some "recommended "practices should be modified to more accurately match ways in which college students responsibly manage their finances. For example, it is not necessarily a sign of poor financial management if an individual who banks online doesn't balance his/her checkbook each month. The individual is 
unlikely to even have a checkbook; instead, the appropriate financial management practice may be to reconcile his/her online account as frequently as needed to avoid an overdraft. On the other hand, paying credit cards on time seems like a good measure of financial management behavior even if the payment is made online. Thus, future researchers should develop a scale of financial management responsibility that fits the financial management options available to college students. The findings from this research could be used to develop a "financial fitness quiz" that could be used as a risk assessment tool by college campuses as well as financial professionals and educators who work with young adults. The research further concludes that the influence of family members is important but complex. Most students reported hearing various messages about money from various family members. Common examples were, "Don't spend money you don't have" and various cautionary statements about credit. Most of the messages students shared related to controlling spending or using credit wisely.

\section{College Students and Financial Literacy: What They Know and What We Need to Learn Eastern Family}

\section{Economics and Resource Management Association 2006 Conference}

This study ${ }^{1}$ investigated the effects of a financial education program on high school student's knowledge of personal finance. A comparison of pretest and posttest scores achieved on a reliable and valid thirty-item instrument suggested that the Financing Your Future curriculum increased financial knowledge across many concepts. The assessment contributes to the growing literature showing that a well-specified and properly implemented program in financial education can positively and significantly influence the financial knowledge of high school students. Financial literacy is important because of its benefits for consumers, the community, and the economy ${ }^{2}$. Financially literate consumers, when compared to financially illiterate consumers, tend to have greater lifetime utility and enjoyment, by having more disposable income, have more savings, save more for retirement, actively manage debt, borrow prudently, and be more realistic about their financial goals. Behavioural economics ${ }^{3}$ and economic psychology can help to explain the shortcoming of traditional approaches to financial education, but more importantly, they can be employed in the design of more effective programmes .Provision of knowledge and information in itself is not sufficient, the information must be incorporated in daily life. Behavioural economics can be used to fine tune a number of existing services and provisions to help improve the efficiency of financial education

1. WALSTAD, W. B., REBECK, K. and MacDONALD, R. A. (2010), The Effects of Financial Education on the Financial Knowledge of High School Students. Journal of Consumer Affairs, 44: 336-357. doi: 10.1111/j.17456606.2010.01172.x

2. WHAT CAUSES SUBOPTIMAL FINANCIAL BEHAVIOUR? AN EXPLORATION OF FINANCIAL LITERACY, SOCIAL INFLUENCES AND BEHAVIOURAL ECONOMICS RESEARCH REPORT Angelo

Capuano ,Ian Ramsay March 2011 Website: http://cclsr.law.unimelb.edu.au/go/centreactivities/research/financial-literacyproject/ index.cfm

\section{Improving Financial Education Efficiency OECD-Bank of Italy symposium on Financial Literacy 2011}

The Reserve Bank of India today released on its website ${ }^{1}$ the draft National Strategy for Financial Education for comments and feedback. Comments can be emailed by August 15, 2012. The National Strategy recognises that financial literacy and financial education play a vital role in financial inclusion and inclusive growth and envisages ways towards creating awareness and educating consumers on access to financial services, availability of various types of products and their features; changing attitudes to translate knowledge into responsible financial behaviour; and making consumers of financial services understand their rights and obligations. The National Strategy seeks to create a financially aware and empowered India. It aims at undertaking a massive Financial Education campaign to help people manage money more effectively to achieve financial well being by accessing appropriate financial products and services through regulated entities with fair and transparent machinery for consumer protection and grievance redressal. The draft National Strategy has been prepared under the aegis of the Sub Committee of the Financial Stability and Development Council (FSDC) and is being simultaneously released for comments by all financial sector regulators.

1. RBI Releases Draft National Strategy for Financial Education for Comments July 16, 2012 www.rbi.in.org Analysis And Results-

Demographics

\begin{tabular}{|c|c|c|}
\hline AGE & Frequency & Percent \\
\hline $20-30$ & 40 & 37.7 \\
\hline $30-40$ & 39 & 36.8 \\
\hline $40-50$ & 16 & 15.1 \\
\hline 50 and above & 10 & 9.4 \\
\hline Total & 105 & 99.1 \\
\hline GENDER & Frequency & 53.8 \\
\hline male & 57 & 45.3 \\
\hline female & 48 & 99.1 \\
\hline Total & 105 & Percent \\
\hline EDUCATIONAL & & 3.8 \\
\hline QUALIFICATION & Frequency & 51.9 \\
\hline under graduate & 4 & 42.5 \\
\hline graduate & 55 & 0.9 \\
\hline post graduate & 45 & 99.1 \\
\hline Doctorate & 1 & Percent \\
\hline Total & 105 & 7.5 \\
\hline INCOME LEVEL & Frequency & 33 \\
\hline below 15000 & 8 & 35 \\
\hline 15000-25000 & 35 & \\
\hline
\end{tabular}




\begin{tabular}{|c|c|c|}
\hline $25000-50000$ & 39 & 36.8 \\
\hline 50000 and above & 13 & 12.3 \\
\hline Total & 105 & 99.1 \\
\hline OCCUPATION & Frequency & Percent \\
\hline student & 9 & 8.5 \\
\hline working & 82 & 77.4 \\
\hline house wife & 4 & 3.8 \\
\hline retired & 3 & 2.8 \\
\hline self employed & 7 & 6.6 \\
\hline Total & 105 & 99.1 \\
\hline
\end{tabular}

Reserve banks initiatives in promoting financial literacy

A thorough review of Reserve Bank Publications and other literature revealed that Reserve bank of India is actively engaged in promotion of financial literacy. The measures taken for the same involves the following:

Multilingual RBI website for the Common Person

-In 13 languages; Financial Education page on RBI's website

Multi-lingual reading material

- Comics books (Raju and Money Kumar series), educational games

- Comic books are becoming popular among children and even among grownups

\section{Awareness programmes}

-Films, skits, road shows

-Participation in exhibitions - stalls on financial education

-Organizing workshops for selected groups

-Financial Education camps in remote places - Outreach visits

-Essay/Quiz competitions; Visits to RBI by school children

-Financial Counselling \& Literacy Centres

-Talks on Radio/Television

- Frequent Press release

The study covers three mediums RBI website for the Common Person, Press release and workshops in detail

\section{Level of financial literacy}

Respondents were asked questions on day to day money management, financial products, financial planning, tax planning and risk management. Those who answered sixty percent of the questions correctly were assumed to be financially literate. According to the study 58 percent of the respondents were found to be financially literate .22 percent of the sample scored below $20 \%$ on financial literacy scale.

\section{Relationship between financial literacy and investment choice decisions}

The correlation coefficient may range from -1 to 1 , where -1 or 1 indicates a "perfect" relationship. The further the coefficient is from 0 , regardless of whether it is positive or negative, the stronger the relationship between the two variables. Notice that the Pearson coefficient for the relationship between awareness of a financial product and investment in the same is not more than 0.500 for any of the investment product, but it is positive for all the investment options. But should we consider the relationship strong It should not surprise us, however, that the relationship is not "perfect" (a coefficient of 1). Awareness appears to be an important predictor of investment pattern, but no doubt you can think of other reasons why people might invest in a particular investment tool.

\begin{tabular}{|c|c|c|c|c|c|c|c|c|c|c|}
\hline & $\begin{array}{l}\text { Do you } \\
\text { currentily hold } \\
\text { a pension } \\
\text { fund } \\
\text { (personally or } \\
\text { jointly)? }\end{array}$ & $\begin{array}{c}\text { Do you } \\
\text { currently } \\
\text { hold an } \\
\text { investment } \\
\text { account } \\
\text { such as } \\
\text { such as } \\
\text { unit trust } \\
\text { (personally } \\
\text { or jointly)? }\end{array}$ & $\begin{array}{c}\text { Do you } \\
\text { currentel } \\
\text { y hold a } \\
\text { mortgag } \\
\text { e } \\
\text { persona } \\
\text { 1ly or } \\
\text { jointly)? }\end{array}$ & $\begin{array}{l}\text { Do you } \\
\text { current1 } \\
\text { y hold a } \\
\text { bank } \\
\text { 1aan } \\
\text { secured } \\
\text { on } \\
\text { property } \\
\text { (persona } \\
\text { lly or or } \\
\text { jointly)? }\end{array}$ & $\begin{array}{c}\text { Do you } \\
\text { currenty hold } \\
\text { an unsecured } \\
\text { bank loan } \\
\text { (personally or } \\
\text { jointly)? }\end{array}$ & $\begin{array}{c}\text { Do you } \\
\text { current1 } \\
\text { y hold a } \\
\text { microfin } \\
\text { ance } \\
\text { ance } \\
\text { loan } \\
\text { persona } \\
\text { 11y or } \\
\text { jointly)? }\end{array}$ & \begin{tabular}{|l} 
Do you \\
currently \\
hold an \\
Insurance \\
(personally \\
or jointly)?
\end{tabular} & $\begin{array}{c}\text { Do you } \\
\text { currently } \\
\text { hold stocks } \\
\text { and shares } \\
\text { (personally } \\
\text { or jointly)? }\end{array}$ & \begin{tabular}{|l|} 
Do you currently \\
hold bonds \\
(personally or \\
jointly)?
\end{tabular} & $\begin{array}{c}\text { Do you } \\
\text { currently } \\
\text { hold mutual } \\
\text { funds } \\
\text { (personally } \\
\text { or jointly)? }\end{array}$ \\
\hline $\begin{array}{l}\text { Financial avareness } \\
\text { about pension fund }\end{array}$ & $.196^{\circ}$ & & & & & & & & & \\
\hline $\begin{array}{l}\text { Financial awareness } \\
\text { about unit trust }\end{array}$ & $\mathrm{x}$ & $.199^{\circ}$ & & & & & & & & \\
\hline $\begin{array}{l}\text { Financial awareness } \\
\text { about mortgage }\end{array}$ & $\mathrm{x}$ & $\mathrm{x}$ & $225^{\circ}$ & & & & & & & \\
\hline $\begin{array}{l}\text { Financial awareness } \\
\text { about bank loan } \\
\text { secured on property }\end{array}$ & $\mathrm{x}$ & $\mathrm{x}$ & $\mathrm{x}$ & $231^{\circ}$ & & & & & & \\
\hline $\begin{array}{l}\text { Financial awareness } \\
\text { about unsecured } \\
\text { bank loan }\end{array}$ & $\mathrm{x}$ & & & & $223 * 1$ & & & & & \\
\hline
\end{tabular}




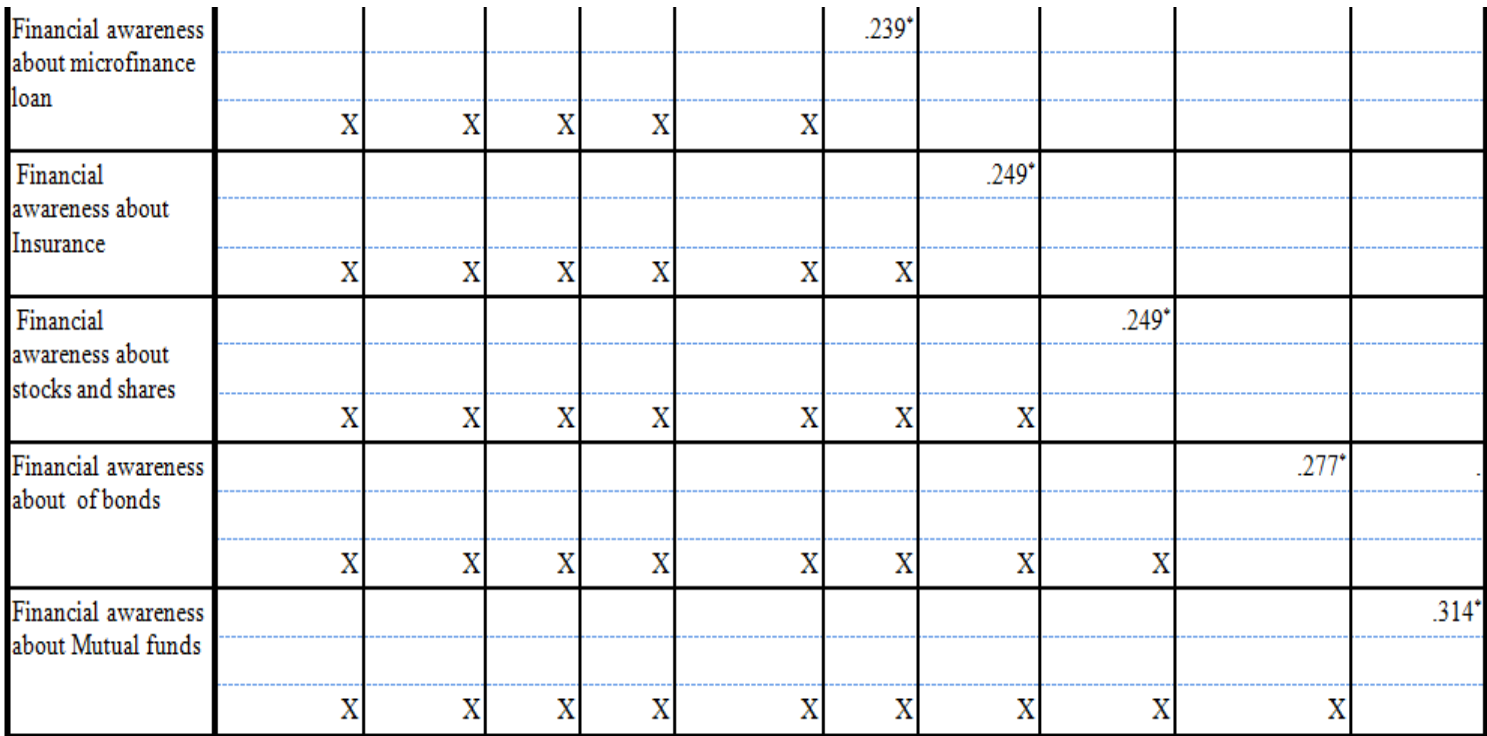

Factor Analysis

During the first phase of data analysis the items of the questionnaire were loaded onto four distinct factors, which were labeled :

1 day to day money management

2 financial control

3 financial satisfaction and security

4 attitude towards spending patterns

The four factors (14 items) with their factor loading are shown in Table below

Important factors having an influence on financial attitude and behavior

\section{Rotated Component Matrix ${ }^{\mathrm{a}}$}

\begin{tabular}{|c|c|c|c|c|}
\hline & \multicolumn{4}{|c|}{ Component } \\
\hline & 1 & 2 & 3 & 4 \\
\hline I keep track of my expenses on a regular basis. & .513 & .474 & .357 & -.084 \\
\hline I put money aside for future purchases or emergencies. & .552 & .560 & -.042 & -.156 \\
\hline I prepare a budget every month. & .807 & .209 & .002 & -.129 \\
\hline $\begin{array}{l}\text { I make goals about how to spend money and I discuss them with } \\
\text { my family. }\end{array}$ & .766 & .130 & .090 & -.191 \\
\hline I earn more money than I spend (I am not in debt). & .393 & -.012 & .641 & -.067 \\
\hline I feel secure in my current financial situation. & -.076 & .235 & .780 & -.204 \\
\hline I feel confident about my financial future. & .133 & .155 & .808 & .035 \\
\hline I pay my monthly bills on time. & .045 & .791 & .084 & -.090 \\
\hline Before I buy something I carefully consider whether I can afford it & -.004 & .774 & .059 & -.092 \\
\hline I tend to live for today and let tomorrow take care of itself & .000 & -.056 & .208 & .764 \\
\hline I keep a close personal watch on my financial affairs & .247 & .587 & .181 & .040 \\
\hline $\begin{array}{l}\text { I am prepared to risk some of my own money when saving or } \\
\text { making an investment }\end{array}$ & .660 & -.003 & .166 & .100 \\
\hline I set long term financial goals and strive to achieve them & .429 & .506 & .151 & .159 \\
\hline $\begin{array}{l}\text { I find it more satisfying to spend money than to save it for the long } \\
\text { term }\end{array}$ & -.053 & .036 & -.339 & .761 \\
\hline Money is there to be spent & -.145 & -.106 & -.161 & .797 \\
\hline
\end{tabular}

Extraction Method: Principal Component Analysis.

Rotation Method: Varimax with Kaiser Normalization

a. Rotation converged in 5 iterations.

Table Reliability Tests for Five Principal Components

\begin{tabular}{|l|c|c|}
\hline Factor & No: of Items & Cronbach alpha value \\
\hline day to day money management & 3 & .798 \\
\hline financial control & 5 & .783 \\
\hline financial satisfaction and security & 3 & .732 \\
\hline attitude towards spending patterns & 3 & .754 \\
\hline
\end{tabular}


It is recommended that Cronbach's alpha coefficient scores are above the 0.7 cut-off value (Nunnally \& Bernstein, 1994). The above Table shows that all the Cronbach's alpha coeffi cient scores were above the recommended 0.7 cut-off value. Therefore, the measuring instrument and items can be regarded as reliable.

Difference in financial behavior and attitude wrt to gender

Next phase of data analysis involved testing whether there is any significance difference in the financial behavior and attitude by male and female customers. For testing the significance difference in means one way ANOVA test was applied

\begin{tabular}{|c|c|c|}
\hline \multicolumn{3}{|l|}{ ANOVA } \\
\hline & $\mathrm{F}$ & Sig. \\
\hline I keep track of my expenses on a regular basis. & 1.125 & .291 \\
\hline \multirow[t]{2}{*}{ I put money aside for future purchases or emergencies. } & .390 & 534 \\
\hline & & \\
\hline I prepare a budget every month. & .008 & 929 \\
\hline \multirow[t]{2}{*}{ I make goals about how to spend money and I discuss them with my family. } & .365 & .547 \\
\hline & & \\
\hline I earn more money than I spend (I am not in debt). & .118 & .732 \\
\hline \multirow[t]{2}{*}{ I feel secure in my current financial situation. } & 9.426 & .003 \\
\hline & & \\
\hline I feel confident about my financial future. & .598 & .441 \\
\hline \multirow{2}{*}{ I pay my monthly bills on time. } & .105 & 747 \\
\hline & & \\
\hline Before I buy something I carefully consider whether I can afford it & .351 & .555 \\
\hline \multirow[t]{2}{*}{ I tend to live for today and let tomorrow take care of itself } & 17.488 & .000 \\
\hline & & \\
\hline I keep a close personal watch on my financial affairs & .440 & .509 \\
\hline \multirow[t]{2}{*}{ I am prepared to risk some of my own money when saving or making an investment } & .210 & .647 \\
\hline & & \\
\hline \multirow[t]{2}{*}{ I set long term financial goals and strive to achieve them } & 226 & 636 \\
\hline & & \\
\hline \multirow[t]{2}{*}{ I find it more satisfying to spend money than to save it for the long term } & 5.263 & .024 \\
\hline & & \\
\hline \multirow[t]{2}{*}{ Money is there to be spent } & 8.544 & .004 \\
\hline & & \\
\hline
\end{tabular}

It was found that, out of 14 variables for four variable there was a significant difference in financial behavior and attitude of male and female customers.

To measure the most effective medium for general financial awareness One-Sample Test

\begin{tabular}{|l|r|r|r|}
\hline & \multicolumn{3}{|c|}{ One-Sample Test } \\
\cline { 2 - 4 } & & \multicolumn{3}{|c|}{} & \multicolumn{1}{|c|}{ Mean Difference } \\
\hline Website & 10.570 & Sig. (2-tailed) & 1.390 \\
Press Releases & 11.820 & .000 & 1.543 \\
Workshops & 2.395 & .000 & .143 \\
\hline
\end{tabular}

From the above table if can be observed that the mean value for press release is more that website. Further analysis to measure whether there is a significant difference between website and press release in context to effectiveness in providing financial awareness T-test was applied and it is found that there is significant difference between the two media 
and we can conclude that press release is the most effective media for creating general financial awareness and workshops are the least.

To measure the most effective medium for Financial Planning for the future

From the table below it can be observed that the mean value for press release is more that website. For further analysis we have applied T-test and it is found that there is significant difference between the two media and we can conclude that press release is the most effective media for Financial Planning for the future and workshops are the least. One-Sample Test

\begin{tabular}{|l|r|r|r|r|}
\hline \multirow{2}{*}{} & \multicolumn{5}{|c|}{} & \\
\cline { 2 - 5 } & \multicolumn{1}{|c|}{$\mathrm{t}$} & $\mathrm{df}$ & Sig. (2-tailed) & Mean Difference \\
\hline Website & 10.144 & 104 & .000 & 1.486 \\
Press Releases & 11.500 & 104 & .000 & 1.686 \\
Workshops & 2.342 & 104 & .021 & .105 \\
\hline
\end{tabular}

To measure the most effective medium to protect you from financial Fraud One-Sample Test

\begin{tabular}{|c|c|c|c|c|}
\hline & $\mathrm{t}$ & $\mathrm{df}$ & Sig. (2-tailed) & Mean Difference \\
\hline Website & 9.894 & 104 & .000 & 1.486 \\
\hline Press Releases & 10.604 & 104 & .000 & 1.419 \\
\hline Workshops & 2.385 & 104 & .019 & .067 \\
\hline
\end{tabular}

From the above table if can be observed that the mean value for press release is more that website . From the results of T-test and it is found that there is significant difference between the two media and we can conclude that press release is the most effective media to provide protection from financial Fraud and workshops are the least.

To measure the most effective medium which helps you in Overcoming a Financial Crisis One-Sample Test

\begin{tabular}{|c|c|c|c|c|}
\hline & \multicolumn{4}{|c|}{ Test Value $=0$} \\
\hline & $\mathrm{t}$ & df & Sig. (2-tailed) & Mean Difference \\
\hline Website & 9.886 & 104 & .000 & 1.345 \\
\hline Press Releases & 10.996 & 104 & .000 & 1.600 \\
\hline Workshops & 2.242 & 104 & .027 & .105 \\
\hline
\end{tabular}

From the above table it can be observed that the mean value for press release is more that website .Further analysis to measure whether there is a significant difference between website and press release in context to overcoming a Financial Crisis T-test was applied and it is found that there is significant difference between the two media and we can conclude that press release is the most effective media for overcoming a Financial Crisis and workshops are the least.

To measure the most effective medium to increase Awareness about Central Banking Function

From the above table it can be observed that the mean value for press release is more that website. For further analysis we have applied T-test and it is found that there is significant difference between the two media and we can conclude that press release is the most effective media for increasing Awareness about Central Banking Functions and workshops are the least.

\begin{tabular}{|c|c|c|c|c|}
\hline & \multicolumn{4}{|c|}{ Test Value $=0$} \\
\hline & $\mathrm{t}$ & df & Sig. (2-tailed) & Mean Difference \\
\hline Website & 9.441 & 103 & .000 & 1.317 \\
\hline Press Releases & 10.458 & 104 & .000 & 1.324 \\
\hline Workshops & 2.224 & 103 & .028 & 087 \\
\hline
\end{tabular}

To measure the most effective medium to increase Knowledge about Financial Markets and Products

From the table below it can be observed that the mean value for press release is more that website Further analysis to measure whether there is a significant difference between website and press release in terms of Knowledge about Financial Markets and Products awareness we have applied T-test and it is found that there is significant difference between 
the two media and we can conclude that press release is the most effective media increase Knowledge about Financial Markets and Products and workshops are the least.

\begin{tabular}{|c|c|c|c|c|}
\hline \multicolumn{5}{|c|}{ One-Sample Test } \\
\hline & \multicolumn{4}{|c|}{ Test Value $=0$} \\
\hline & $\mathrm{t}$ & $\mathrm{df}$ & Sig. (2-tailed) & Mean Difference \\
\hline Website & 9.899 & 104 & .000 & 1.410 \\
\hline Press Releases & 10.363 & 104 & .000 & 1.352 \\
\hline Workshops & 2.359 & 104 & .020 & .076 \\
\hline
\end{tabular}

To measure the most effective medium which helps in making Better Investment Decisions One-Sample Test

\begin{tabular}{|c|c|c|c|c|}
\hline & \multicolumn{4}{|c|}{ Test Value $=0$} \\
\hline & $\mathrm{t}$ & $\mathrm{df}$ & Sig. (2-tailed) & Mean Difference \\
\hline Website & 9.661 & 104 & .000 & 1.352 \\
\hline Press Releases & 10.477 & 104 & .000 & 1.352 \\
\hline Workshops & 2.385 & 104 & .019 & .067 \\
\hline
\end{tabular}

from the above table if can be observed that the mean value for press release is more that website further analysis to measure whether there is a significant difference between website and press release in context to making Better Investment Decisions. For further analysis we have applied T-test and it is found that there is significant difference between the two media and we can conclude that press release is the most effective media for making better investment decision and workshops are the least.

\section{Conclusion And Suggestions}

From the results of the survey it can be concluded that press release is the most effective medium for increasing financial literacy with respect to increasing general financial awareness, financial planning for the future , protection from fraud, overcoming a financial crisis, awareness about central banking functions, knowledge about financial markets and products. Financial education website could be updated regularly and be made interactive to increase the efficiency of workshops it is suggested that they are conducted more frequently and on a mass scale

Initiatives which would be welcome by public includes

$>\quad$ Making financial education a part of school curriculum

$>$ Financial literacy centers in colleges

$>$ Workshops in colleges and universities

$>$ Inviting or holding weekly workshops for the common man at central and regional offices

$>$ Weekly column of financial education in major newspapers

$>$ Targeted outreach camps for women and retired persons

$>$ Short term Refresher course on basics of financial management

\section{Limitations}

This study assumes that all information gathered for this research project is accurate. The study also assumes that participants will be truthful and honest in their responses but understands that there is an emotional issue often associated with money discussions that sometimes causes participants to be guarded in their responses. Another limitation of this study is the narrow geographical sample of participants filling out the survey

\section{Refrences}

[1] 'The Role of Financial Education: The Indian Case' - Inaugural Address by Dr. Y. V. Reddy, Governor, Reserve Bank of India at the International Conference on Financial Education organised by OECD and co-hosted by Pension Fund Regulatory and Development Authority at New Delhi on September 21, 2006.www.rbi.in.org

[2] Financial Behavior and Problems among College Students in Malaysia: Research and Education Implication Mohamad Fazli Sabri, Iowa State University, consumer interest annual Volume 54, 2008

[3] Personal finance- Jack R Kapoor, Les R Dlabay, Robert J Hughes eight edition 2008 tata mcgraw Hills Publication

[4] SURVEY OFFINANCIAL LITERACY SCHEMES IN THE EU27VT Markt/2006/26H - Final Report Marco Habschick, Britta Seidl, Dr. Jan Evers with cooperation of Doreen Klose and Yoshua Parsian Hamburg, November 2007

[5] Factors Influencing Investment Decision of Generations in India: An Econometric Study Gaurav Kabra, Prashant Kumar Mishra , Manoj Kumar Dash Asian journal of management research 2010

[6] Financial Literacy of Youth. A Sensitivity Analysis of the Determinants Samy M., Tawfik H., Huang R. and Nagar A. K. International Journal of Economic Sciences and Applied Research 1 (1): 55-70 55 